\title{
ANALISIS NILAI EKONOMI PERIKANAN SETU PATOK DESA SETU PATOK, KECAMATAN MUNDU, KABUPATEN CIREBON
}

\author{
Fany Noor Fadilla \\ DIII PBB/Penilai Jurusan Pajak PKN STAN \\ Alamat Korespondensi : fanynoorfadilla55@gmail.com
}

\section{INFORMASI ARTIKEL}

Diterima Pertama

[31 Juli 2020]

Dinyatakan Diterima

[4 September 2020]

KATA KUNCI:

Penilaian Ekonomi, Danau Setu Patok, Perikanan Tangkap, Production Function Approach, Nilai Pasar

KLASIFIKASI JEL:

Q1, Q2, Q5

\section{ABSTRAK}

Setu Patok is a small lake located in Setu Patok Village, Mundu Sub District, Cirebon Districts, West Java Province. Currently it is used as a source of agricultural irrigation, fishing ground, and tourism object. However, all these uses have not been carried out optimally. In this study, the benefits studied were only devoted to fishery utilization in order to find out the Setu Patok Fisheries Economic Value (NEP). The study uses the Production Function Approach or Market Based Aproach method, which measures the value of environmental goods and services based on market value. The study used primary data through direct interviews with fishermen. As a result, it was found that the Setu Patok NEP was IDR 421,494,000/year.

Setu Patok adalah sebuah danau kecil yang berada di Desa Setu Patok, Kecamatan Mundu, Kabupaten Cirebon, Provinsi Jawa Barat. Saat ini dimanfaatkan sebagai sumber irigasi pertanian, perikanan tangkap dan objek wisata. Namun, semua pemanfaatan tersebut belum dilakukan secara optimal. Dalam penelitian ini, manfaat yang diteliti dikhususkan hanya pada manfaat langsung khususnya perikanan tangkap dengan tujuan untuk mengetahui Nilai Ekonomi Perikanan (NEP) Setu Patok. Penelitian menggunakan metode Production Function Approach atau Market Based Aproach yaitu mengukur nilai barang dan jasa lingkungan berdasarkan nilai pasar. Penelitian menggunakan data primer melalui wawancara langsung dengan para nelayan. Hasilnya, didapat bahwa NEP Setu Patok adalah sebesar Rp 421.494.000/tahun. 


\section{PENDAHULUAN}

Wilayah perairan adalah bagian yang tidak terpisahkan dari Indonesia. Sebagai negara kepulauan terbesar di dunia, mayoritas wilayah negara Indonesia adalah perairan. Perbandingan luas wilayah perairan dengan total wilayah Indonesia adalah dua per tiga. Wilayah perairan tersebut terdiri dari laut, danau, sungai dan lainnya. Salah satunya yang sangat bermanfaat bagi kehidupan sosial, lingkungan dan ekonomi masyarakat adalah danau. Pada umumnya, danau memiliki peranan yang begitu penting bagi masyarakat sekitarnya karena memberikan berbagai manfaat langsung maupun tidak langsung.

Objek dari penelitian ini adalah Setu Patok yang terletak di Desa Setu Patok, Kecamatan Mundu, Kabupaten Cirebon, Provinsi Jawa Barat. Luasnya $\pm 175 \mathrm{Ha}\left( \pm 1,75 \mathrm{~km}^{2}\right)$ dengan kapasitas daya tampung air sebanyak $\pm 3.790 .000 \mathrm{~m}^{3}$. Berdasarkan luas dan juga volumenya, menurut Kementerian Lingkungan Hidup (KLH) (2010), danau dapat dibagi menjadi empat kelompok yaitu kelompok besar, medium, kecil dan sangat kecil.

\begin{tabular}{lrr}
\hline \multicolumn{1}{c}{ Klasifikasi } & \multicolumn{1}{c}{ Luas $(\mathrm{km} 2)$} & Volume $\left(\right.$ juta $\left.\mathrm{m}^{3}\right)$ \\
\hline Besar & $10.000-1.000 .000$ & $10.000-1.000 .000$ \\
Medium & $100-10.000$ & $100-10.000$ \\
Kecil & $1-100$ & $1-100$ \\
Sangat kecil & $<1$ & $<1$
\end{tabular}

Maka, berdasarkan klasifikasi dari Kementerian Lingkungan Hidup tersebut, Setu Patok termasuk ke dalam kelompok danau kecil.

Saat ini, Setu Patok dimanfaatkan sebagai sumber perikanan tangkap, irigasi pertanian dan objek wisata. Namun dengan semua potensi tersebut, pemanfaatannya hingga saat ini masih belum optimal. Kurangnya perhatian pemerintah terhadap pengelolaan dan pemanfaatan salah satu aset daerah ini mengakibatkan banyaknya potensi yang belum dimaksimalkan. Pengelolaan kebersihan dan penyediaan tempat sampah belum memadai, sarana wisata masih sangat kurang serta sarana irigasi pertanian yang minim. Hal ini mungkin disebabkan karena kurangnya pengetahuan akan potensi yang sebenarnya dari Setu Patok. Salah satu cara untuk mengetahui potensi itu adalah dengan mengetahui nilai ekonominya. Oleh karena itu, penelitian ini dilakukan dengan tujuan untuk menghitung dan menganalisis nilai ekonomi dari Setu Patok dengan mengkhusukan pada salah satu manfaatnya yaitu perikanan tangkap. Nilai ekonomi akan dipandang dari dua sisi yakni berdasarkan harga jual nelayan kepada tengkulak/pengumpul dan harga jual pada konsumen akhir untuk mengetahui nilai yang lebih sesuai. Diharapkan penelitian ini dapat menjadi referensi bagi pemerintah Kabupaten Cirebon untuk melakukan pengelolaan dan pemanfaatan Setu Patok yang berkelanjutan dan juga melengkapi penelitianpenelitian terdahulu.

\section{KERANGKA TEORI}

\subsection{Sumberdaya Perairan Situ}

Berdasarkan Peraturan Menteri Negara Lingkungan Hidup Nomor 28 Tahun 2009, danau adalah wadah air dan ekosistemnya yang terbentuk secara alamiah. Dalam pengertian ini termasuk juga situ yaitu istilah lokal untuk menyebut danau kecil. Menurut Puspita (2005), situ adalah salah satu bentuk ekosistem perairan tergenang yang berukuran kecil dan bersalinitas rendah atau tawar. Istilah situ biasanya digunakan oleh masyarakat Jawa Barat. Kemudian penyebutan tersebut diadaptasikan lagi oleh masyarakat daerah Cirebon menjadi setu.

Secara umum, danau memiliki tiga manfat yaitu manfaat ekologis, ekonomis dan sosial budaya. Manfaat ekologis terkait dengan habitat berbagai macam flora dan fauna, fungsi hidrologis dan juga penjaga keberlangsungan berbagai sistem alami yang terjadi di alam. Manfaat ekonomis terkait dengan potensinya sebagai sumber mata pencaharian, seperti di bidang perikanan tangkap, sumber irigasi pertanian ataupun objek pariwisata. Terakhir manfaat sosial budaya yaitu keberadaan danau adalah penentu pola hidup, kebudayaan, serta sebagai penentu pola atau sumber mata pencaharian masyarakat sekitar (Puspita, 2005).

Berdasarkan struktur fisiknya, danau dapat dibagi menjadi dua zona yaitu zona litoral dan zona limnetik. Zona litoral adalah bagian danau yang mendapatkan cahaya matahari yang cukup sehingga menjadi tempat hidup berbagai macam jenis biota seperti tumbuhan air, invertebrata dan ikan. Sedangkan zona limnetik cenderung mendapatkan cahaya matahari yang lebih sedikit dan merupakan tempat hidup biota air lainnya seperti crustacea kecil.

Di Setu Patok, komunitas biologis yang dimanfaatkan hanyalah yang tinggal di zona litoral khususnya ikan. Jenis-jenis ikan tersebut adalah ikan nila (Oreochromis niloticus), ikan mas (Cyprinus carpio), ikan mujair (Oreochromis mossambicus), ikan kakap (Lates calcalifer), dan ikan betik (Anabas testudineus). Dahulu, crustacea kecil yakni udang air tawar juga biasa ditangkap oleh nelayan namun sekarang sudah tidak pernah ditemukan kembali.

\subsection{Nilai Ekonomi Sumber Daya Alam dan Lingkungan}

Menurut Fauzi (2006), sumber daya didefinisikan sebagai suatu yang dipandang memiliki nilai ekonomi. Sumber daya juga dapat diartikan sebagai komponen ekosistem yang menghasilkan barang dan jasa yang bermanfaat untuk manusia. Manfaat tersebut terdiri dari nilai guna (use value) dan nilai non guna (non use value). Kemudian nilai guna dapat dibagi kembali menjadi nilai guna langsung (direct use value) dan nilai guna tidak langsung (indirect use value). Apabila keseluruhan nilai tersebut dijumlahkan, maka akan 
didapat Nilai Ekonomi Total (NET) yang mewakili nilai suatu objek sumber daya alam dan lingkungan.

Perikanan tangkap yang menjadi objek penelitian ini adalah salah satu jenis nilai guna langsung dari sumber daya alam dan lingkungan Setu Patok. Hasil nilainya disebut dengan Nilai Ekonomi Perikanan (NEP). Untuk mengukur manfaat atau nilainya, terdapat beberapa metode yang dapat digunakan. Diantaranya adalah Production Function Approach yaitu sebuah metode penilaian sumber daya alam dan lingkungan yang dapat digunakan untuk menilai barang dan jasa lingkungan berdasarkan nilai pasar (Market Based Approach). Metode ini juga biasa disebut sebagai pendapatan faktor neto atau pendekatan nilai yang diperoleh, karena nilai sumber daya didapat dari pengurangan antara penerimaan dengan biaya yang dikeluarkan dalam memanfaatkan sumber daya tersebut. Dengan metode ini, nilai sumber daya dapat diketahui berdasarkan harga pasarnya. Oleh karena itu untuk dapat menggunakan metode ini, sumber daya harus memenuhi kriteria memiliki nilai di pasaran. Umumnya digunakan untuk memperkirakan nilai ekonomi dari produk atau jasa ekosistem yang berkontribusi terhadap produksi barang yang dipasarkan secara komersial.

\subsection{Penelitian Terdahulu}

Terdapat banyak penelitian yang telah dilakukan mengenai nilai ekosistem sungai, danau dan juga situ. Umumnya penelitian tersebut dilakukan untuk mengetahui Nilai Ekonomi Total (NET) sehingga semua manfaat dari objek penelitian baik itu nilai guna maupun nilai non guna diidentifikasi. Namun, yang membedakan penelitian ini dengan penelitian terdahulu adalah penelitian ini mengkhususkan penilaian pada satu jenis manfaat saja, yaitu nilai guna langsung perikanan tangkap yang kemudian diidentifikasi dari dua sisi yakni berdasarkan harga jual nelayan kepada tengkulak/pengumpul dan harga jual pada konsumen akhir untuk mengetahui bagaimana manfaat ekonomi yang sebenarnya.

Oleh karena belum adanya pembanding dari penelitian-penelitian sebelumnya yaitu yang memfokuskan pada penilaian perikanan tangkap, maka hasil nilai penelitian ini akan dibandingkan dengan komponen nilai perikanan (NEP) dari NET penelitian terdahulu.

Asnil (2012), meneliti tentang analisis penilaian ekonomi dan kebijakan pemanfaatan sumberdaya danau yang berkelanjutan dengan studi kasus Danau Maninjau Sumatera Barat. Diperoleh NET sebesar Rp 350.921.949.238 dengan Nilai Ekonomi Perikanan (NEP) per tahun adalalah Rp 119.315.669.236.

Widyaningsih (2015), meneliti tentang penilaian ekonomi Situ Gede, Kelurahan Situ Gede, Kecamatan Bogor Barat, Kota Bogor. Diperoleh NET Situ Gede sebesar Rp 3.797.302.971 per tahun. Nilai total ekonomi tersebut terdiri dari NEP sebesar Rp 2.621.740.000 per tahun.
Ismail (2016), meneliti tentang nilai manfaat ekonomi dan pengelolaan waduk dengan studi kasus Waduk Ir. H. Juanda. Hasilnya adalah nilai ekonomi manfaat langsung total adalah Rp149.266.389.756 per tahun dengan NEP sebesar Rp44.524.512.963 per tahun.

Penelitian terdahulu dengan objek Setu Patok pernah dilakukan namun bukan dengan tujuan meneliti nilai ekonominya melainkan untuk mengetahui potensinya sebagai objek wisata. Maka diharapkan dengan adanya penelitian ini dapat melengkapi penelitian-penelitian terdahulu serta menjadi referensi bagi pemerintah Kabupaten Cirebon dan Provinsi Jawa Barat untuk lebih meningkatkan perhatian terhadap pengelolaan dan pemanfaatan Setu Patok yang berkelanjutan.

\section{METODE PENELITIAN}

Data yang digunakan dalam penelitian ini terdiri dari data primer yang diperoleh dengan cara melakukan wawancara langsung kepada responden serta observasi secara langsung di lokasi penelitian. Responden adalah nelayan yang biasa melakukan penangkapan ikan di Setu Patok. Data yang diperlukan untuk dapat menghitung nilai manfaat perikanan tangkap adalah jenis dan banyak ikan, harga jual ikan serta biaya yang dikeluarkan untuk menangkap ikan.

Pada penelitian sejenis yaitu Widyaningsih (2015), meneliti tentang penilaian ekonomi Situ Gede, Kelurahan Situ Gede, Kecamatan Bogor Barat, Kota Bogor, rumus yang digunakan untuk menghitung nilai manfaat perikanan tangkap adalah sebagai berikut :

$$
\mathrm{NM}=\left[\left(\sum_{i=1}^{n} \text { PYi. Yi }\right)-\left(\sum_{i=1}^{n} \mathrm{PXi}\right)\right]
$$

Keterangan:

$\mathrm{NM}=$ Nilai Manfaat Dari Pancingan Ikan

(Rupiah per Kg per Tahun)

$\mathrm{PYi}=$ Harga Ikan (Rupiah per Kg)

$\mathrm{Yi}_{\mathrm{i}}=$ Hasil Pancingan Ikan (Kg per Tahun)

$\mathrm{PXi}=$ Biaya Penangkapan Ikan (Rupiah)

$\mathrm{i} \quad=$ Jenis ikan (bawal, mujair, patin,....dll )

Dalam penelitian ini, rumus tersebut disesuaikan dengan jenis-jenis ikan yang ada di Setu Patok. Berdasarkan hasil wawancara dengan responden, diketahui ikan yang biasa mereka tangkap terdiri dari lima jenis yaitu ikan nila, mas, kakap, mujair, dan betik. Sehingga rumusnya menjadi :

$$
\mathrm{NM}=\left[\left(\sum_{i=1}^{5} \mathrm{PYi} . \mathrm{Yi}\right)-\left(\sum_{i=1}^{5} \mathrm{PXi}\right)\right]
$$

Keterangan:

$\mathrm{NM}=$ Nilai Manfaat Dari Pancingan Ikan

(Rupiah per Kg per Tahun)

PYi = Harga Ikan (Rupiah per Kg) 


$$
\begin{array}{ll}
Y i & =\text { Hasil Pancingan Ikan (Kg per Tahun) } \\
\mathrm{PXi} & =\text { Biaya Penangkapan Ikan (Rupiah) } \\
\mathrm{i} & =\text { Jenis ikan (nila, mas, kakap, mujair, dan betik) }
\end{array}
$$

\section{HASIL PENELITIAN}

\subsection{Gambaran Umum Lokasi}

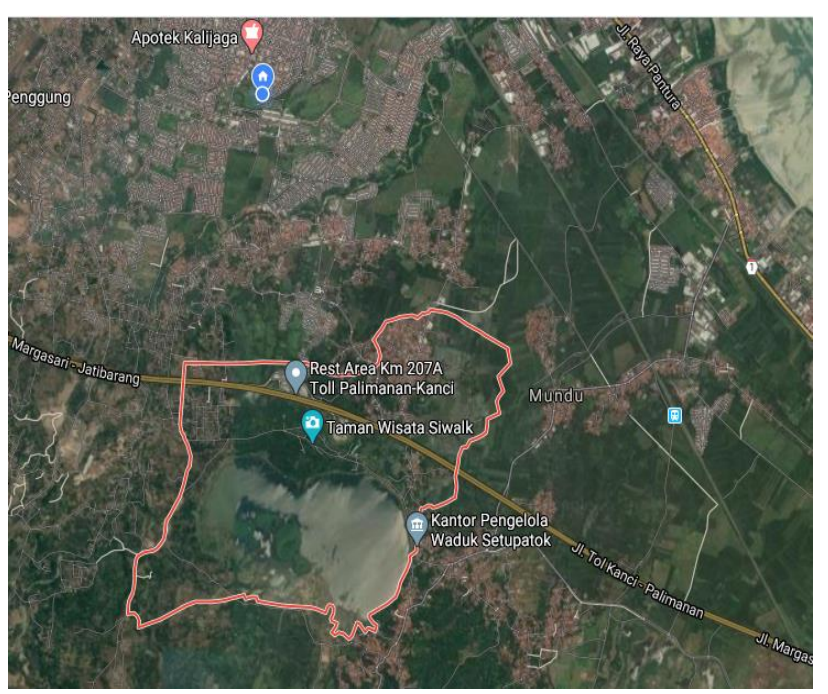

Objek penelitian adalah Setu Patok, yaitu sebuah situ atau danau kecil yang terletak di Desa Setu Patok, Kecamatan Mundu, Kabupaten Cirebon, Provinsi Jawa Barat. Berjarak $6 \mathrm{~km}$ dari pusat kota Cirebon ke arah Kota Tegal dengan titik koordinat $6.7862011^{\circ} \mathrm{S}$ $108.5648065^{\circ} \mathrm{E}$. Luasnya sekitar $\pm 175 \mathrm{Ha}$ dengan daya tampung air sebanyak $\pm 3.790 .000 \mathrm{~m}^{3}$.

Setu Patok terletak di wilayah dataran rendah dengan ketinggian antara 0-10 $\mathrm{m}$ dari permukaan air laut. Lokasi Setu Patok beriklim tropis dengan suhu minimum $24^{\circ} \mathrm{C}$ dan suhu rata-rata $28^{\circ} \mathrm{C}$. Kelembaban berkisar antara $\pm 48-93 \%$ dengan curah hujan rata-rata $\pm 2.260 \mathrm{~mm} /$ tahun.

Ciri khas Setu Patok adalah panorama alamnya yang sangat indah berupa hamparan perairan yang cukup jernih, bukit kecil ditengahnya serta Gunung Ciremai sebagai latar belakang. Udara sejuk dan pemandangan matahari terbenam yang indah membuat tempat ini tidak pernah kehilangan pesona terutama pada sore hari. Itulah mengapa danau ini sebenarnya sangat potensial untuk dijadikan tempat wisata.

Setu Patok adalah sebuah aset berharga untuk Kabupaten Cirebon namun saat ini, pengelolaannya belum optimal sehingga manfaat yang dirasakan pun belum begitu besar. Hal itu terlihat dari sarana prasarana yang kurang memadai serta terdapat beberapa potensi yang belum dikelola misalnya sebagai sumber air bersih. Saat ini, potensi yang sudah dimanfaatkan adalah sebagai sumber air untuk perikanan tangkap, irigasi pertanian, dan objek wisata. Sayangnya, untuk dapat mengakses lokasi ini dapat dikatakan cukup sulit karena tidak adanya sarana transportasi umum sehingga jika ingin berkunjung harus menggunakan kendaraan pribadi.

\subsection{Gambaran Umum Pemanfaatan Perikanan Setu Patok}

Berdasarkan wawancara dengan lima responden, semuanya mengungkapkan bahwa nelayan atau menangkap ikan bukanlah pekerjaan utama. Rata-rata pekerjaan utama mereka adalah buruh pabrik sohun yang banyak berdiri di kawasan Setu Patok. Ada juga yang membuat batu bata di pinggiran danau atau berdagang dengan membuka usaha warung di sekitar danau. Hal ini dikarenakan hasil perikanan di Setu Patok tidak cukup memuaskan. Selain itu air yang surut ketika musim kemarau membuat para nelayan harus memiliki pekerjaan lain jikalau penghasilan dari ikan tangkap tidak ada sama sekali.

Untuk waktu penangkapan dalam satu tahun, para nelayan tidak dapat melakukannya sepanjang tahun melainkan hanya 7 bulan sebelum akhirnya air danau akan surut di musim kemarau sehingga menangkap ikan tidak memungkinkan. Ketika dilakukan wawancara pun, terlihat air sudah mulai menyusut. Informasi lain yang didapatkan dari responden adalah diperkirakan ada total 30 orang nelayan yang biasa menangkap ikan di Setu Patok. Nelayan-nelayan tersebut rata-rata melakukan trip sebanyak 22 kali setiap bulannya.

Ikan yang berada di Setu Patok berasal dari bibit ikan hasil swadaya masyarakat dan bibit yang tidak sengaja terbawa oleh arus sungai dari sumber air Setu Patok. Sumber air tersebut adalah tiga sungai yang hulunya berada di kaki gunung Ciremai, daerah Kuningan. Sampai dengan wawancara dilakukan, pemerintah daerah Cirebon tidak pernah turut dalam upaya pembibitan ikan di danau ini. Padahal pada danau sejenis di sekitaran daerah Cirebon selalu dilakukan pembibitan secara rutin oleh pemerintahnya.

Jenis tangkapan yang ada di Setu Patok hanyalah ikan air tawar yaitu yaitu ikan nila, mas, kakap, mujair dan betik dengan jenis ikan utama adalah ikan nila. Penyebabnya karena ikan ini lebih mudah untuk beradaptasi dan berkembang biak. Beberapa tahun lalu, masih dapat ditemukan spesies udang air tawar namun kini sudah tidak pernah ditemukan lagi.

Pemanfaatan Setu Patok sebagai tempat penangkapan ikan hanya dilakukan oleh masyarakat sekitar, khususnya masyarakat Desa Sinarancang dan Setu Patok. Mereka biasanya menggunakan alat tangkap ikan yang sederhana seperti jaring, jala dan juga rakit/getek hasil buatan sendiri dimana alat-alat tersebut masuk ke dalam biaya tetap. Sedangkan untuk biaya variabel tidak ada, karena nelayan tidak memerlukan umpan ataupun bahan bakar transportasi dikarenakan rakit/getek adalah transportasi non mesin. Mereka biasanya pergi ke tengah danau pada sore hari untuk menebar jaring setelah itu kembali lagi ke daratan. Barulah dipagi harinya mereka kembali ke tengah danau untuk mengambil hasil tangkapan. Oleh karena itu, biaya variabel berupa biaya makan dan penerangan saat menangkap ikan pun tidak ada. 


\subsection{Nilai Ekonomi Perikanan Setu Patok}

Untuk menghitung nilai ekonomi didapat data bahwa peralatan yang digunakan untuk menangkap ikan adalah jaring, getek/rakit dan jala. Jenis ikan yang didapat adalah ikan nila, mas, kakap, mujair, dan betik. Setiap nelayan biasa melakukan penangkapan ikan dalam satu bulan rata-rata 22 hari dan hanya 7 bulan dalam satu tahun. Hasil tangkapan yang didapat tiap nelayan rata-rata sebanyak $64,60 \mathrm{~kg} /$ bulan sehingga dalam satu tahun rata-ratanya $452,20 \mathrm{~kg} /$ tahun. Total nelayan adalah 30 orang sehingga dalam satu tahun sebanyak 13.566 kg ikan bisa ditangkap dari Setu Patok dengan rincian ikan nila $7.728 \mathrm{~kg} /$ tahun, ikan mas 882 kg/tahun, ikan kakap 924 kg/tahun, ikan mujair 2.562 $\mathrm{kg} /$ tahun dan ikan betik $1.470 \mathrm{~kg} /$ tahun.

Sementara itu biaya yang dikeluarkan oleh setiap nelayan hanya biaya tetap berupa nilai penyusutan alat tangkap ikan per tahun yang terdiri dari penyusutan jaring sebesar $\mathrm{Rp} \mathrm{420.000/tahun,} \mathrm{penyusutan}$ getek/rakit sebesar Rp 300.000/tahun, dan penyusutan jala sebanyak $\mathrm{Rp} 66.000 /$ tahun sehingga totalnya $\mathrm{Rp}$ 786.000 per tahun per nelayan. Maka total biaya untuk semua nelayan adalah $\mathrm{Rp}$ 23.580.000/tahun dengan biaya terbesar pada jaring yaitu Rp 12.600.000/tahun kemudian getek/rakit Rp 9.000.000/tahun dan terkahir jala sebesar Rp 1.980.000/tahun.

Berdasarkan keterangan responden, harga jual kepada tengkulak untuk setiap jenis ikan adalah ikan nila Rp 20.000/kg, ikan mas Rp 20.000/kg, ikan kakap Rp 20.000/kg, ikan mujair Rp 15.000/kg, dan ikan betik $\mathrm{Rp} 10.000 / \mathrm{kg}$. Maka total pendapatan yang dapat diperoleh dari perikanan tangkap jika dilihat dari sisi nelayan adalah $\mathrm{Rp} 243.810 .000 /$ tahun dengan manfaat bersih sebesar Rp 220.230.000/tahun.

Nilai Manfaat Perikanan Tangkap Berdasarkan Harga yang Diperoleh Nelayan

\begin{tabular}{|c|c|c|c|c|}
\hline No & Uraian & $\begin{array}{c}\text { Harga per } \\
\text { satuan }(\mathrm{Rp} / \mathrm{kg})\end{array}$ & $\begin{array}{c}\text { Jumlah } \\
\text { (kg/tahun) }\end{array}$ & Nilai (Rp/tahun) \\
\hline \multirow[t]{7}{*}{1} & \multicolumn{4}{|c|}{ PENDAPATAN } \\
\hline & 1. Nila & 20,000 & $7,728.00$ & $154,560,000$ \\
\hline & 2. Mas & 20,000 & 882.00 & $17,640,000$ \\
\hline & 3. Kakap & 20,000 & 924.00 & $18,480,000$ \\
\hline & 4. Mujair & 15,000 & $2,562.00$ & $38,430,000$ \\
\hline & 5. Betik & 10,000 & $1,470.00$ & $14,700,000$ \\
\hline & \multicolumn{3}{|c|}{ Total Pendapatan } & $243,810,000$ \\
\hline \multirow[t]{5}{*}{ II } & \multicolumn{4}{|l|}{ BIAYA } \\
\hline & \multicolumn{3}{|l|}{ Jaring } & $12,600,000$ \\
\hline & \multicolumn{3}{|c|}{ Getek/rakit } & $9,000,000$ \\
\hline & \multicolumn{3}{|l|}{ Jala } & $1,980,000$ \\
\hline & \multicolumn{3}{|c|}{ Total Biaya } & $23,580,000$ \\
\hline III & MANFAA & T BERSIH & $13,566.00$ & $220,230,000$ \\
\hline
\end{tabular}

Namun, jika dilihat dari rantai distribusi ekonomi mulai dari tengkulak hingga konsumen akhir, manfaat bersih atau nilai ekonomi perikanan tangkap Setu Patok sebenarnya lebih besar. Terdapat perbedaan yang cukup signifikan antara harga yang diterima oleh nelayan dari tengkulak dengan harga ke konsumen akhir. Harga setiap jenis ikan untuk konsumen akhir adalah ikan nila Rp 32.000/kg, ikan mas Rp 32.000/kg, ikan kakap Rp 55.000/kg, , ikan mujair Rp 32.000/kg, dan ikan betik $\mathrm{Rp} 25.000 / \mathrm{kg}$. Sehingga total pendapatannya menjadi Rp 445.074.000/tahun dengan manfaat bersih Rp 421.494.000/tahun.

\begin{tabular}{llrr}
\multicolumn{5}{c}{ Nilai Manfaat Perikanan Tangkap Berdasarkan Harga } \\
Konsumen Akhir
\end{tabular}

\section{SIMPULAN DAN SARAN}

\subsection{Simpulan}

Total nilai manfaat perikanan tangkap Setu Patok dapat dipandang dari dua sisi. Pertama adalah nilai manfaat yang diperoleh nelayan yang dihitung berdasarkan harga dari tengkulak kepada nelayan dengan manfaat bersih sebesar Rp 220.230.000/tahun. Kedua, manfaat bersih total untuk semua pelaku industri perikanan tangkap yang dihitung berdasarkan harga konsumen akhir yaitu sebesar Rp 421.494.000/tahun. Menurut peneliti, nilai yang lebih sesuai untuk dijadikan Nilai Ekonomi Perikanan (NEP) Setu Patok adalah Rp 421.494.000/tahun karena mencakup total manfaat yang diperoleh perekonomian dengan adanya keberadaan Setu Patok. Dua nilai manfaat ini memiliki perbedaan yang cukup jauh dikarenakan terdapat perbedaan harga antara yang diterima nelayan dengan harga konsumen akhir dengan rata-rata perbedaannya mencapai dua kali lipat atau $200 \%$.

Kemudian jika dibandingkan dengan NEP pada penelitian sejenis, NEP Setu Patok jauh lebih kecil yang disebabkan oleh beberapa faktor. Pertama, karena waktu menangkap ikan dalam satu tahun hanya 7 bulan sedangkan pada penelitian lain rata-rata 10 bulan. Kedua, pengelolaan perikanan khusunya penebaran bibit secara berkala oleh Pemerintah tidak pernah dilakukan. Hanya mengandalkan swadaya dari para nelayan sehingga hasil tangkapannya menjadi kurang optimal. Oleh karena dua faktor itu juga akhirnya para nelayan tidak menjadikan kegiatan menangkap ikan sebagai pekerjaan utama mereka.

\subsection{Saran}

1. Peran aktif Pemerintah Daerah dan lembaga kemasyarakatan sangat dibutuhkan untuk mengelola Setu Patok secara berkelanjutan 
khususnya pada sektor perikanan tangkap sehingga potensinya dapat dimanfaatkan secara optimal.

2. Kesejahteraan para nelayan harus lebih diperhatikan dengan mengatur secara adil tingkat harga ikan mulai dari nelayan hingga ke konsumen akhir.

\section{DAFTAR PUSTAKA (REFERENCES)}

Syukur, Mat, dkk. (1986). Analisa Biaya Dan Keuntungan Usaha Penangkapan Ikan Skala Kecil Di Langkat, Sumatera Utara

Widyaningsih. (2015). Penilaian Ekonomi Situ Gede, Kelurahan Situ Gede, Kecamatan Bogor Barat, Kota Bogor. Institut Pertanian Bogor

Ismail. (2016). Nilai Manfaat Ekonomi Dan Pengelolaan Waduk (Studi Kasus Waduk Ir. H. Juanda). Prosiding Seminar Nasional Lahan Basah Tahun 2016

Asnil. (2012). Analisis Penilaian Ekonomi Dan Kebijakan Pemanfaatan Sumberdaya Danau yang Berkelanjutan (Studi Kasus Danau Maninjau Sumatera Barat). Program Pascasarjana IPB Bogor 